\title{
МОДЕЛЮВАННЯ МЕРЕЖІ НАДАННЯ ПУБЛІЧНИХ СЕРВІСІВ ТА ПОСЛУГ У СФЕРІ КУЛЬТУРИ ХАРКІВСЬКОЇ ОБЛАСТІ
}

\author{
Н. А. Плотнік, \\ здобувач кафедри регіонального розвитку та місиевого самоврядування \\ Харківський регіональний інститут Наџіональної Академії державного управління при \\ Президентові Украӥни, Украӥна \\ ORCID ID: https://orcid.org/0000-0002-2268-6926
}

DOI: https://doi.org/10.31435/rsglobal_ijitss/31052020/7061

\section{ARTICLE INFO}

Received 27 March 2020

Accepted 12 May 2020

Published 31 May 2020

\section{KEYWORDS}

public services, service activity

of public authorities,

unified database of cultural

institutions.

\begin{abstract}
In the article the author considers the peculiarities of modeling the basic network of cultural institutions of local level in Kharkiv region, the use of scientific methods and approaches during modeling, identifies problems in ensuring the provision of quality cultural services by cultural institutions and services to local communities.
\end{abstract}

Citation: Plotnik N. A. (2020) Simulation of Public and Culture Services Provision Network in Kharkiv Region. International Journal of Innovative Technologies in Social Science. 4(25). doi: 10.31435/rsglobal_ijitss/31052020/7061

Copyright: (C) 2020 Plotnik N. A. This is an open-access article distributed under the terms of the Creative Commons Attribution License (CC BY). The use, distribution or reproduction in other forums is permitted, provided the original author(s) or licensor are credited and that the original publication in this journal is cited, in accordance with accepted academic practice. No use, distribution or reproduction is permitted which does not comply with these terms.

Виклад основного матеріалу Реформа децентралізації влади в Україні вважається однією 3 найуспішніших реформ. Перерозподіл владних повноважень сприяє формуванню нової системи відносин між різними гілками влади, налагодженню нових зв'язків між регіонами та згуртованості людей у територіальних громадах навколо долучення до процесів державотворення, економічного розвитку територій та якісного надання послуг населенню. Аналіз проведення першого етапу реформи показав, що нові громади, маючи традиційні економіко-географічні чинники (природні, енергетичні, культурні, туристичні, людські ресурси), разом із новими повноваженнями отримують і нові можливості для забезпечення достойного рівня життя мешканців громади, а також позитивні зрушення у формуванні локальної ідентичності об'єднаних територіальних громад.

Однак, слід зазначити, що поряд із позитивними зрушеннями проведення реформи децентралізації мають місце й деякі проблемні питання, пов'язані із інституційною недостатністю та відсутністю в органах місцевого самоврядування необхідного кадрового забезпечення. Вочевидь, що ці фактори є джерелом ризиків у питанні посилення спроможності громади з надання якісних публічних сервісів та послуг населенню.

Публічні послуги - блага, які не мають уречевленої форми, що надаються фізичними і юридичними особами, органами державної влади, органами місцевого самоврядування, підприємствами, установами, організаціями будь-яких форм власності, у вигляді цілеспрямованих корисних дій чи обслуговування. Залежно від суб'єкта, що надає публічні 
послуги, розрізняють державні, муніципальні та громадські послуги. Важливою складовою як державних, так і муніципальних послуг є адміністративні послуги $[1,148]$.

Сервісна діяльність органів публічної влади - функція публічного врядування, сутність якої полягає в наданні управлінських послуг фізичним та юридичним особам, які є їх одержувачами - клієнтами (споживачами), а публічні службовці - надавачами (виконавцями), що реалізують ці послуги від імені держави $[1,160]$.

В умовах зміни курсу державної політики на сервісно-орієнтовану, коли змінюються курс дій органів влади та «сукупність засобів (механізмів, інструментів, важелів, способів)» [1, 161], зважаючи на досвід проведення секторальної децентралізації у сфері освіти, соціального захисту населення, охорони здоров'я, енергетиці тощо, важливим питанням для культурної децентралізації $\epsilon$ побудова ефективної інституційної системи з надання якісних публічних сервісів і послуг населенню.

Авторкою статті разом із працівниками Управління культури і туризму Харківської обласної державної адміністрації в рамках реалізації завдань «Концепції реформування системи забезпечення населення культурними послугами» (розпорядження Кабінету Міністрів України від 23 січня 2019 року №27) було проведено інвентаризацію базової мережі закладів культури місцевого рівня Харківської області, а саме клубних та бібліотечних закладів, мистецьких шкіл та кінотеатрів.

Існуюча мережа закладів культури Харківської області нараховує 651 клубний заклад, 808 бібліотечних закладів, 79 мистецьких шкіл та 11 кінотеатрів та виглядає наступним чином (Табл. 1)

Таблиця 1.

\begin{tabular}{|c|c|c|}
\hline Назва мережі & Перелік закладів культури & $\begin{array}{c}\text { Кількість об'єктів } \\
\text { наявної мережі }\end{array}$ \\
\hline \multirow{5}{*}{ Клубні заклади } & Будинки культури & 311 \\
\hline & клуби & 314 \\
\hline & народні доми & 1 \\
\hline & Центри культури, дозвілля, спорту & 17 \\
\hline & Палаци культури & 8 \\
\hline \multirow{3}{*}{ Бібліотеки } & Публічні бібліотеки & 749 \\
\hline & Публічні бібліотеки для дітей & 52 \\
\hline & Публічні бібліотеки для юнацтва & 7 \\
\hline \multirow{4}{*}{ Мистецькі школи } & Музичні школи & 56 \\
\hline & Школи мистецтв & 15 \\
\hline & Художні школи & 7 \\
\hline & Хореографічні школи & 1 \\
\hline Кінотеатри & Кінотеатри & 11 \\
\hline
\end{tabular}

За підсумками проведення інформаційно - аналітичної роботи було зібрано інформацію про кожний заклад мережі та сформовано єдину базу даних, основними атрибутами якої $є$ назва та приналежність закладу до типів закладів культури, територіально-адміністративне розташування із зазначенням адреси (Табл. 2.). 
Таблиця 2.

\begin{tabular}{|c|c|c|c|c|c|c|c|c|c|c|}
\hline № $3 / \Pi$ & 告 & 战充 & $\begin{array}{c}\text { тип } \\
\text { населе- } \\
\text { ного } \\
\text { пункту }\end{array}$ & область & район & $\begin{array}{c}\text { Населений } \\
\text { пункт }\end{array}$ & Вулиця & 首 & $\begin{array}{c}\text { Повна назва } \\
\text { закладу }\end{array}$ & $\begin{array}{c}\text { Форма } \\
\text { власності }\end{array}$ \\
\hline 1 & 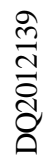 & 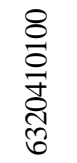 & місто & $\begin{array}{c}\text { Хар- } \\
\text { ківська }\end{array}$ & $\begin{array}{l}\text { Барвін- } \\
\text { ківський }\end{array}$ & Барвінкове & Центральна & 9 & $\begin{array}{c}\text { Барвінківський } \\
\text { районний Будинок } \\
\text { культури }\end{array}$ & комунальна \\
\hline 2 & $\begin{array}{l}\frac{8}{2} \\
\frac{\sigma}{\delta}\end{array}$ & 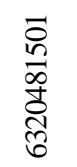 & село & $\begin{array}{c}\text { Хар- } \\
\text { ківська }\end{array}$ & $\begin{array}{l}\text { Барвін- } \\
\text { ківський }\end{array}$ & $\begin{array}{c}\text { Африка- } \\
\text { нівка }\end{array}$ & Миру & 17 & $\begin{array}{c}\text { Африканівський } \\
\text { сільський Будинок } \\
\text { культури }\end{array}$ & комунальна \\
\hline 3 & $\begin{array}{l}\frac{\infty}{2} \\
\frac{\mathfrak{2}}{2} \\
\stackrel{2}{8}\end{array}$ & 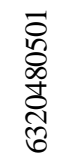 & село & $\begin{array}{c}\text { Хар- } \\
\text { ківська }\end{array}$ & $\begin{array}{l}\text { Барвін- } \\
\text { ківський }\end{array}$ & Богодарове & Миру & 5 & $\begin{array}{c}\text { Богодарівський } \\
\text { сільський Будинок } \\
\text { культури }\end{array}$ & Комунальна \\
\hline 4 & $\begin{array}{l}\frac{\pi}{2} \\
\frac{\pi}{\delta}\end{array}$ & 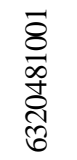 & село & $\begin{array}{c}\text { Хар- } \\
\text { ківська }\end{array}$ & $\begin{array}{l}\text { Барвін- } \\
\text { ківський }\end{array}$ & $\begin{array}{c}\text { Велика } \\
\text { Комишуваха }\end{array}$ & Центральна & 1 & $\begin{array}{c}\text { Велико- } \\
\text { комишуваський } \\
\text { сільський Будинок } \\
\text { культури }\end{array}$ & комунальна \\
\hline 5 & 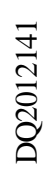 & 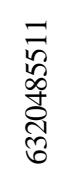 & село & $\begin{array}{c}\text { Хар- } \\
\text { ківська }\end{array}$ & $\begin{array}{l}\text { Барвін- } \\
\text { ківський }\end{array}$ & $\begin{array}{c}\text { Василівка } \\
\text { Друга }\end{array}$ & Весняна & 67 & $\begin{array}{c}\text { Василівський } \\
\text { сільський Будинок } \\
\text { культури }\end{array}$ & комунальна \\
\hline 6 & 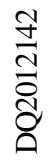 & 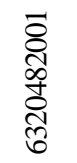 & село & $\begin{array}{c}\text { Хар- } \\
\text { ківська }\end{array}$ & $\begin{array}{l}\text { Барвін- } \\
\text { ківський }\end{array}$ & Грушуваха & Миру & 6 & $\begin{array}{c}\text { Грушуваський } \\
\text { сільський Будинок } \\
\text { культури }\end{array}$ & комунальна \\
\hline 7 & 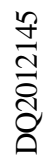 & 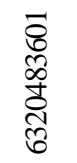 & селище & $\begin{array}{c}\text { Хар- } \\
\text { ківська }\end{array}$ & $\begin{array}{c}\text { Барвін- } \\
\text { ківський }\end{array}$ & Іванівка & Шкільна & 20 & $\begin{array}{c}\text { II-Іванівський } \\
\text { сільський Будинок } \\
\text { культури }\end{array}$ & комунальна \\
\hline 8 & 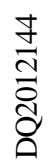 & 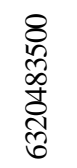 & село & $\begin{array}{c}\text { Хар- } \\
\text { ківська }\end{array}$ & $\begin{array}{l}\text { Барвін- } \\
\text { ківський }\end{array}$ & Іванівка & Миру & 12 & $\begin{array}{c}\text { Іванівський } \\
\text { сільський Будинок } \\
\text { культури }\end{array}$ & комунальна \\
\hline 9 & 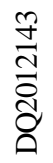 & 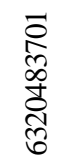 & село & $\begin{array}{c}\text { Хар- } \\
\text { ківська }\end{array}$ & $\begin{array}{l}\text { Барвін- } \\
\text { ківський }\end{array}$ & Рідне & Центральна & $61-A$ & $\begin{array}{c}\text { Іллічівський } \\
\text { сільський Будинок } \\
\text { культури }\end{array}$ & комунальна \\
\hline 10 & 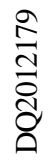 & 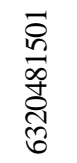 & село & $\begin{array}{c}\text { Хар- } \\
\text { ківська }\end{array}$ & $\begin{array}{c}\text { Барвін- } \\
\text { ківський }\end{array}$ & Котовка & Миру & 12 & $\begin{array}{c}\text { Котовський } \\
\text { сільський Будинок } \\
\text { культури }\end{array}$ & комунальна \\
\hline
\end{tabular}

До бази даних також включалася інформація щодо чисельності населення громади на території якої знаходиться заклад, режиму роботи закладу, кількості штатних працівників, матеріально-технічного забезпечення. Всю інформацію було візуалізовано у вигляді електронної карти (рис. 1). 


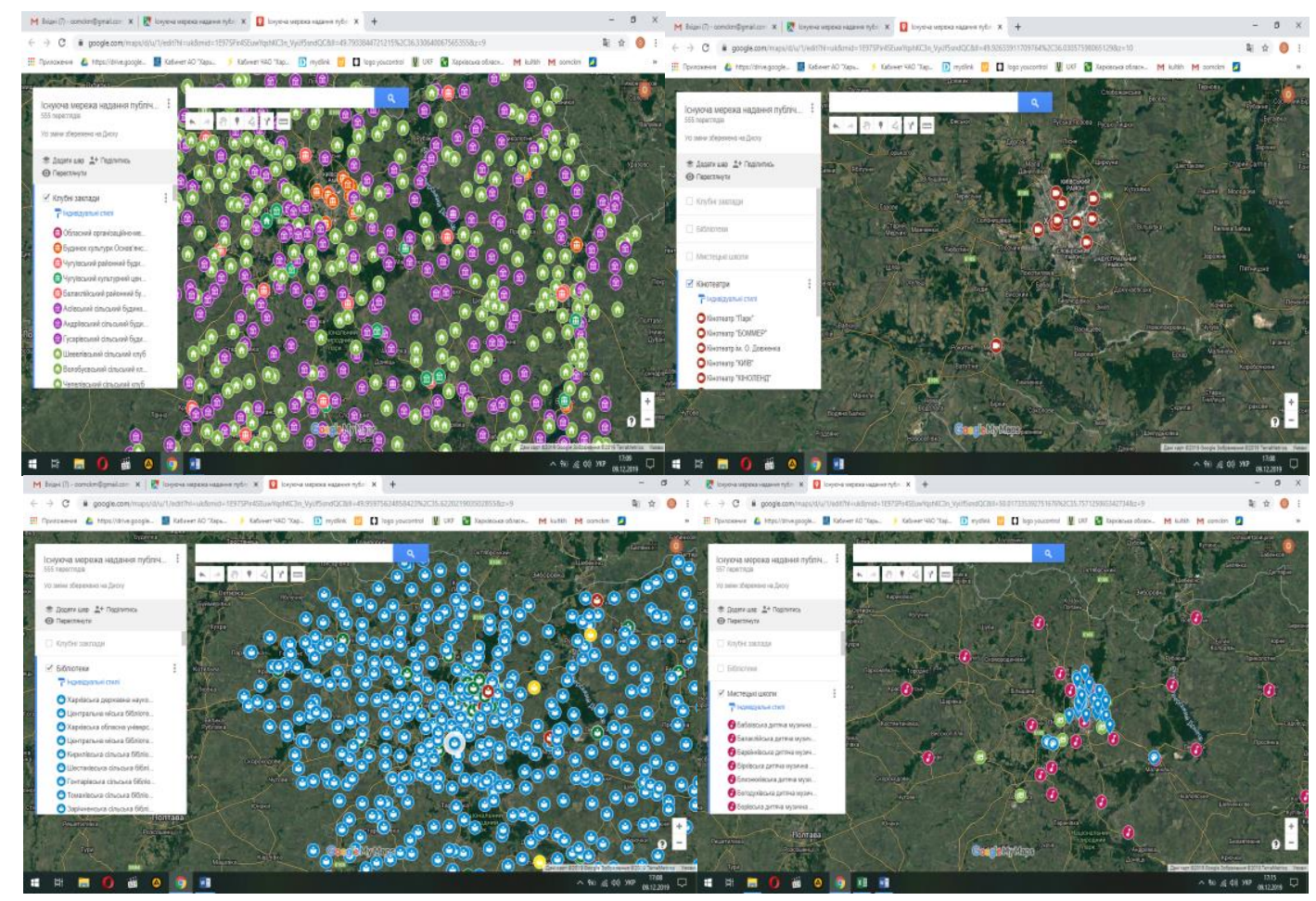

Puc. 1

На другому етапі проведення реформи культурна децентралізація є однією з пріоритетних напрямів для зміцнення державності, оскільки «як системо утворюючий фактор єднання і розквіту суспільства на регіональному та національному рівнях культура $є$ важливим інструментом його соціального, економічного і політичного розвитку» [2, 2]. Тому перед закладами культури (клубами, Палацами культури, бібліотеками, музеями тощо, які в сукупності складають базову мережу закладів культури місцевого рівня [3]), постають важливі завдання: - «створення умов для збільшення кількості, підвищення якості та доступності культурних послуг, розвитку людського капіталу України через стимулювання створення та споживання культурних послуг» $[2,5]$.

Формування зазначеної вище бази даних закладів культури надало можливість :

- провести моделювання мережі надання публічних сервісів та послуг у сфері культури;

- провести аналіз існуючої базової мережі закладів культури, іiі відповідності до Концепції реформування системи забезпечення населення культурними послугами ;

- сформувати нову модель майбутньої мережі закладів культури Харківської області, яка буде відповідати завданню секторальної децентралізації по забезпеченню населенню доступу до якісних культурних послуг;

- створити електронні Google карти існуючої та перспективної мережі закладів культури Харківської області.

На жаль, під час проведення першого етапу реформи децентралізації влади в Україні аспект культурної децентралізації не здобув належного розвитку у повній мірі. Це пов'язано як із між територіальною диференціацією базової мережі закладів культури, так із забезпеченням дотримання державних стандартів, діючих у сфері культури $[4 ; 5 ; 6]$.

За даними аналізу, проведеним восени 2019 року Міністерством культури України, понад 65\% населення України мають «відносно пропорційну територіальну і фінансову доступність лише до послуг бібліотек, мистецьких шкіл, клубних закладів, на базі яких функціонують і аматорські мистецькі колективи, гуртки або влаштовуються виставки» $[7,1]$. Недостатнє фінансування галузі, застаріла матеріально-технічна база, збільшення кількості працюючих в галузі кадрів без спеціальної фахової освіти, а також зменшення кількості сільського населення створює підгрунтя для територіальної нерівності у забезпеченні державою доступу та надання якісних культурних послуг.

Моделювання мережі існуючих закладів культури надало можливість керівникам галузі культури різних рівнів (область, місто, район, громада) забезпечити в нових умовах не тільки 
проведення успішного управління діяльністю закладів культури з надання якісних культурних сервісів та послуг, але й ефективне використання та розподіл фінансових та певних ресурсів.

Слід зазначити, що під час роботи над моделюванням зазначеної мережі були використані підходи та методи наукового аналізу інформації, серед яких:

- системний підхід, сутність якого полягає у комплексному досліджені базової мережі закладів культури області як системи та окремо їі елементів системи (підвидів закладів культури);

- структурно-функціональний підхід при виділенні в системних об'єктах структурних елементів (компонентів - типів закладів культури; підсистем - видів закладів культури) i визначенні їхньої ролі (функцій) у системі;

- інформаційний підхід, суть якого полягала в тому, що при вивченні базової мережі закладів культури області було зібрано необхідні дані, проведено верифікацію зібраних даних, а також виявлено найхарактерніші інформаційні аспекти;

- метод системного аналізу для вивчення як системи (базової мережі закладів культури місцевого рівня) в цілому, так і сукупності взаємодіючих між собою елементів - окремих закладів культури;

- метод класифікації - багатоступінчатий, послідовний поділ досліджуваної системи (базової мережі закладів культури області) з метою систематизації, поглиблення й отримання нових знань щодо іiі побудови, існуючих та нових елементів системи (підвидів закладів культури), підсистеми (видів закладів культури) та компонентів (типів закладів культури), особливостей внутрішніх і зовнішніх зв'язків;

- метод структуризації «дерево цілей» під час розподілу основної цілі дослідження на декілька під цілей, що дозволило провести поетапний збір, аналіз та обробку необхідних даних з послідуючим переходом до їх геокодування;

- метод моделювання для створення нових підвидів закладів культури (клуббібліотека, центр культури і дозвілля), які пропонується створити на території територіальних громад після проведення відповідного процесу оптимізації;

- візуальний (графічний) метод для внесення інформації в Excel таблиці та геокодування даних (створення Google карт).

Під час верифікації бази геоданих існуючих об'єктів всі роботи виконувалися в Google My Maps. Створюючи електронний облік існуючих об'єктів культурної інфраструктури, відображалися всі заклади, яких не було в базі даних; заклади, де була неправильно зазначена реальна адреса розташування (декомунізація, об'єднання закладів в громадах, різна юридична та фактична адреса), а також заклади, які входили до мережі, але вже давно не функціонували у зв'язку із аварійним станом або відсутністю власних приміщень, що з часом були знищені.

Під час вироблення пропозицій з оптимізації існуючих закладів культури, створення нової моделі закладів культури з подальшим внесенням даних до електронної Google карти «Перспективна оптимізація базової мережі закладів культури Харківської області» аналітичний метод використовувався у більш широкому сенсі, а саме при аналізуванні щільності населення на території моделювання та розрахунку зон доступності до існуючих закладів культури; виявлення територій 3 надмірно щільним / недостатнім їх розміщенням відповідно до нормативів, визначених у Стандартах; визначенні відповідності існуючої мережі закладів культури перспективному стандарту доступності культурних послуг (Стандарти моделювання публічних сервісів та послуг).

Таким чином, проводячи моделювання мережі закладів культури місцевого рівня 3 надання публічних сервісів та послуг, авторка статті разом із колегами управлінцями не тільки мала можливість дослідити існуючу базову мережу закладів культури області як систему, але й шляхом практичного розчленування іiї на окремі члени системи (клуби, бібліотеки, мистецькі школи, кінотеатри) вивчити сучасний стан та виявити проблеми подальшого функціонування закладів на території населених пунктів 3 кількістю населення до 1 тис. осіб, а також розробити проекти нових моделей закладів культури для об'єднаних територіальних громад.

Під час аналізу проекту майбутньої моделі мережі закладів культури області було визначено населенні пункти в яких заклади культури потребують проведення ліквідації, оптимізації або зміни формату закладів культури (створення клубу-бібліотеки, публічної бібліотеки з окремими відділами замість філій, комплексних центрів 3 надання культурних послуг - центрів культури і дозвілля, культурно-дозвіллєвих центрів, культурно-спортивних 
комплексів). Членами робочої групи враховувались не тотожність новоутворених закладів існуючим типам та видам культурних інституцій, а їх подібність до оригіналу.

Таке створення нових моделей закладів культури на території територіальних громад не тільки розширить спектр надання культурних послуг населенню, але й дозволить змінити функції діяльності закладів та вдосконалити роботу їх працівників.

Створення дієвої мережі закладів культури області вимагає постійної наукової підтримки, потребує координації зусиль як Управління культури i туризму ХОДА, так i представників органів виконавчої влади, місцевого самоврядування структурних підрозділів у сфері культури на місцях.

\section{ЛIТЕРАТУРА}

1. Публічне управління: термінол. слов. / уклад.: В. С. Куйбіда, М. М. Білинська, О. М .Петрос та ін. ; за заг. ред. В. С. Куйбіди, М. М. Білинської, О. М. Петрос. - Київ : НАДУ, 2018. - 224 с. - С. 148, 160, 161.

2. Розпорядження Кабінету Міністрів України від 23 січня 2019 р. №27-р. «Концепція реформування системи забезпечення населення культурними послугами»

3. Постанова Кабінету Міністрів України від 24 жовтня 2012 р. №984 «Порядок формування базової мережі закладів культури»

4. Постанова Кабінету Міністрів України від 12 листопада 1998 р. № 1775 «Про нормативи забезпечення населення клубними закладами»

5. Постанова Кабінету Міністрів України від 06 лютого 2019 р. №72 «Про затвердження Державних соціальних нормативів забезпечення населення публічними бібліотеками в Україні»

6. Наказ Міністерства культури і мистецтв України від 08 серпня 1997 року №423 «Про затвердження «Нормативів мінімальної кількості міських і сільських кіновидовищних закладів»

7. Моделювання мереж надання ПУБЛІЧНИХ СЕРВІСІВ ТА ПОСЛУГ. Жовтень 2019. - С.14. [Електронний ресурс] // Кабінет Міністрів України офіційний веб-портал. - Режим доступу: https://decentralization.gov.ua/news/11726

8. Підготовка спроможної мережі надання послуг: Мінрегіон провів тематичні навчання представників ОДА [Електронний ресурс] - Режим доступу: https://decentralization.gov.ua/news/11764 